\title{
Genetic diversity in cowpea landraces analyzed by ISSR markers
}

\author{
L.B.R. Araújo, L.B.C. Fiege, A.V.A Silva and C.H.C.M. Bertini
}

Universidade Federal do Ceará, Fortaleza, CE, Brasil

Corresponding author: L.B.R. Araújo

E-mail: lindabrenna@gmail.com

Genet. Mol. Res. 18 (1): gmr18082

Received July 18, 2018

Accepted February 07, 2019

Published March 28, 2019

DOI http://dx.doi.org/10.4238/gmr18082

\begin{abstract}
The cowpea, Vigna unguiculata (Fabeaceae) is widely cultivated in semi-arid regions, such as northeast Brazil. Due to the low crop yields in this region, it would be useful to develop cultivars adapted to these climate conditions. Landraces are seen as an important source of germplasm to be used in breeding programs of this species due to their good adaptation to the environment, but for this strategy to be viable, their genetic variability must be studied. To this end, we evaluated the genetic diversity, using ISSR molecular markers, of 52 samples of cowpea landraces collected mostly from small producers from all over the state of Ceará, Brazil. The DNA of the genotypes was extracted and analyzed using 25 primers. Based on the electrophoresis profiles of the bands, a genetic dissimilarity matrix was prepared, and a cluster analysis made using the UPGMA and modified Tocher methods. Fourteen primers amplified 80 bands, of which 61 were polymorphic, generating a polymorphism rate of $76 \%$. The selected markers were efficient in identifying genetic variability among the varieties under evaluation, providing a large amount of information. The polymorphic information content varied from 0.13 to 0.66 and the band frequency ranged from 0.01 to 1.00 . The two clustering methods agreed in the number of groups formed $(n=6)$, with the genetic distances ranging from 0.05 to 0.31 , values considered low, suggesting a narrow genetic base for the landraces of this species in Ceará state.
\end{abstract}

Key words: Vigna unguiculata; Genetic diversity; Molecular markers; Germplasm collection 


\section{INTRODUCTION}

The cowpea, Vigna unguiculata (Fabeaceae) is a legume of African origin that has great importance in tropical and subtropical regions of the planet; it is widely cultivated in Africa, Southeast Asia, southwest North America and Latin America (Tan et al., 2012). Interest has been expressed in the crop due particularly to its high nutritional value, especially the high protein content of the seeds, and due to its performance in semi-arid regions, where it is a source of subsistence by many populations (Egbadzor et al., 2014, Chen et al., 2017).

Food security sought by these populations can be facilitated by a combination of various factors, such as conservation agriculture and the use of varieties adapted to the environment, which enables farmers to respond to changing climate (Thierfelder et al., 2016). Recent years have seen an increased appreciation of genetic plant resources and cowpea landraces that are well adapted to local agroclimatic conditions (Stoilova and Berova, 2014).

Such varieties correspond to genotypes conserved by farmers that have not undergone conventional breeding (Fonseca et al., 2015), but which have been cultivated for several cycles in environments to which they are adapted. Some years ago, because most people depended on a small number of modern varieties for various crops, there was concern about conservation of genetic resources (Brush, 1991); but now, in addition to conservation, better use of these resources is also required.

In the semi-arid region of Brazil, the cowpea is traditionally cultivated by family farmers who make use of local varieties and preserve them for future crops. The state of Ceará is the largest producer in the region, producing over 55 thousand tons in 2016; however, this is mainly due to the large planted area, since productivity is low in the state $(272.5 \mathrm{~kg} / \mathrm{ha})$ (Embrapa, 2016). Due to the great importance of the crop, it is necessary to make better use of genetic resources adapted to the region in order to contribute to the development of cultivars that are more resistant to biotic and abiotic stress, that are more productive and that would be accepted by farmers.

In order for the use of these genotypes to be optimized in breeding programs, their genetic diversity must be evaluated. The cowpea shows great variability for some morphological characteristics, such as seed color and pod type, but its genetic diversity appears to be narrow (Gajera et al., 2014). Creole varieties, which have undergone little selection, may have a broader genetic base and could contribute substantially to improving the species.

In order to evaluate genetic diversity in cowpeas, various descriptors can be used. However, molecular markers, which are a direct reflection of genetic polymorphism at the DNA level present advantages, such as high reproducibility and simplicity, and they are particularly indicated for use in analyses of a large number of samples (Tantasawat et al., 2010).

Among these markers, Inter Simple Sequence Repeats (ISSRs), stand out because they generate a large amount of genetic information. As they are highly polymorphic in plant populations, they alow for consistent, reliable, and low-cost genotyping (Almeida et al., 2009; Wang et al., 2009).

In view of the above, we evaluated the genetic diversity of cowpea landraces in the state of Ceará using ISSR molecular markers and compared them with selected control cultivars. This allowed us to correctly identify genotypes in the Cowpea Germplasm Collection of the Federal University of Ceará and select the most promising crosses.

\section{MATERIAL AND METHODS}

\section{Plant material and DNA extraction}


The study included 52 landraces of cowpea collected from small producers at fairs and markets in different regions of the State of Ceará (CE), and five control cultivars registered at the Active Cowpea Germplasm Bank of the Federal University of Ceará (Table 1).

Table 1. Selected cowpea genotypes in Ceará state and their origin.

\begin{tabular}{|c|c|c|c|}
\hline NO. & IDENTIFICATION & GENOTYPE & ORIGIN \\
\hline \multicolumn{4}{|c|}{ Landraces } \\
\hline 1 & CCE-002 & Chumbinho & Barbalha \\
\hline 2 & CCE-003 & Maranhão & Barbalha \\
\hline 3 & CCE-005 & Unknown & Deputado Irapuan Pinheiro \\
\hline 4 & CCE-006 & Canapu & Deputado Irapuan Pinheiro \\
\hline 5 & CCE-007 & Pingo-de-ouro & Deputado Irapuan Pinheiro \\
\hline 6 & CCE-008 & Feijão-de-arrancada & Deputado Irapuan Pinheiro \\
\hline 7 & CCE-010 & Sempre-verde & Deputado Irapuan Pinheiro \\
\hline 8 & CCE-012 & Feijão-de-moita vermelho & Guaraciaba do Norte \\
\hline 9 & CCE-013 & Sempre-verde & Guaraciaba do Norte \\
\hline 10 & CCE-014 & Feijão-moitinha & Guaraciaba do Norte \\
\hline 11 & CCE-015 & Feijão-de-corda & Guaraciaba do Norte \\
\hline 12 & CCE-018 & Pitiúba & Morada Nova \\
\hline 13 & CCE-019 & Pingo-de-ouro & Morada Nova \\
\hline 14 & CCE-020 & Epace-10 & Morada Nova \\
\hline 15 & CCE-024 & Feijão-da-bahia & Parambu \\
\hline 16 & CCE-026 & Cojó & Parambu \\
\hline 17 & CCE-027 & Santo Inácio & Parambu \\
\hline 18 & CCE-030 & Zé Artur & Paramoti \\
\hline 19 & CCE-031 & Roxim-miúdo & Paramoti \\
\hline 20 & CCE-036 & Cara-preta & São Benedito \\
\hline 21 & CCE-037 & Xique-xique & São Benedito \\
\hline 22 & CCE-038 & Manteiga & Umari \\
\hline 23 & CCE-048 & Engana-mulher & Farias Brito \\
\hline 24 & CCE-049 & Feijão-de-corda & Farias Brito \\
\hline 25 & CCE-051 & Paulistinha & Umirim \\
\hline 26 & CCE-052 & Azulão & General Sampaio \\
\hline 27 & CCE-053 & Meio-tardão & General Sampaio \\
\hline 28 & CCE-056 & Ligeiro & General Sampaio \\
\hline 29 & CCE-059 & Olho de coruja & Farias Brito \\
\hline 30 & CCE-061 & Canapu & Várzea Alegre \\
\hline 31 & CCE-062 & Sempre-verde & Farias Brito \\
\hline 32 & CCE-063 & Canapu-ligeiro & Farias Brito \\
\hline 33 & CCE-071 & Azulão & Farias Brito \\
\hline 34 & CCE-072 & Manteiga & Farias Brito \\
\hline 35 & CCE-083 & Feijão-de-corda & Trairi \\
\hline 36 & CCE-084 & Vinagre & Apuiarés \\
\hline 37 & CCE-096 & Russiano & Ocara \\
\hline 38 & CCE-102 & Bagem-mole & Baixo Acaraú \\
\hline 39 & CCE-106 & 40 dias & Farias Brito \\
\hline 40 & CCE-107 & Galanjão & Farias Brito \\
\hline 41 & CCE-109 & Mané-mestre & Tururu \\
\hline 42 & CCE-110 & Roxão & Apuiarés \\
\hline 43 & CCE-119 & Concebida & Juazeiro do Norte \\
\hline 44 & CCE-120 & Cabeça-de-gato & Juazeiro do Norte \\
\hline 45 & SDA-01 & Pingo de Ouro & Choró \\
\hline 46 & SDA-02 & Cara de Gato & Unknown \\
\hline 47 & SDA-03 & Raul & Quixeramobim \\
\hline 48 & SDA-04 & Vinagre Barrigudo de Caldo & Unknown \\
\hline 49 & SDA-05 & Cojó & Unknown \\
\hline 50 & SDA-06 & Boi Deitado & Unknown \\
\hline 51 & SDA-07 & Manteiguinha & Unknown \\
\hline 52 & SDA-08 & Pingo de Ouro & Unknown \\
\hline \multicolumn{4}{|c|}{ Cultivars } \\
\hline 53 & CE-25 & Sempre verde & UFC/Fortaleza \\
\hline 54 & CE-31 & Pitiúba & UFC/Fortaleza \\
\hline 55 & CE-612 & Canapun & UFC/Fortaleza \\
\hline 56 & CE-930 & Pingo de ouro & Limoeiro do Norte \\
\hline 57 & CE-939 & Paulistinha & Morada Nova \\
\hline
\end{tabular}


To extract the genomic DNA, young leaves of the 57 genotypes were used, as per the protocol described by Doyle and Doyle (1990). The quality of the DNA was verified by electrophoresis in $1 \%$ agarose gel, selecting samples that presented well-defined bands with no drag or retention in the wells. Quantification and purity (A260/A280 absorbance ratio) were evaluated using a NanoDrop 2000 (Thermo Scientific ${ }^{\circledR}$ - Waltham, Massachusetts, USA) spectrophotometer. Only samples with values in the 1.8 to 2.0 range were selected for the study, indicating an absence of contaminants (Thermo Scientific, 2010).

\section{ISSR Analysis}

Twenty-five ISSR primers (Integrated DNA Technologies ${ }^{\circledR}$ - Coralville, Iowa, USA) were used to evaluate the polymorphism of the genotypes under study; 16 that produced sharp bands were selected. Amplification reactions were carried out with a final volume of $15 \mu \mathrm{L}$, using PCR Buffer (1x), dNTPs ( $0.2 \mathrm{mM}$ each), $\mathrm{MgCl}_{2}(2 \mathrm{mM})$, primer $(0.8$ $\mu \mathrm{M}$ ), genomic DNA (30 ng/ $\mu \mathrm{L}$ ) and Taq DNA polymerase (1U) (GoTaq Flexi DNA Polymerase, Promega ${ }^{\circledR}$ ). The THERM-1000 thermocycler (Axygen $\left.{ }^{\circledR}\right)$ program consisted of an initial denaturation at $94^{\circ} \mathrm{C}$ for $5 \mathrm{~min}$ and 40 cycles of denaturation, annealing and extension, in addition to a final extension at $72^{\circ} \mathrm{C}$ for $10 \mathrm{~min}$. Each cycle consisted of $94^{\circ} \mathrm{C}$ for $1 \mathrm{~min}, 45^{\circ} \mathrm{C}, 48^{\circ} \mathrm{C}, 50^{\circ} \mathrm{C}$ or $55^{\circ} \mathrm{C}$ for $30 \mathrm{~s}$ (according to the primers used) and $72^{\circ} \mathrm{C}$ for 1 min.

The amplified products were subjected to $1.2 \%$ agarose gel electrophoresis in $0.5 \mathrm{x}$ TBE buffer ( $45 \mathrm{mM}$ Tris-borate, $\mathrm{pH} 8.0$, and $1 \mathrm{mM}$ EDTA) at a current of 90 volts for 1.5 $\mathrm{h}$. The gels were stained with ethidium bromide $(10 \mathrm{ng} / \mathrm{mL})$ and then visualized and photographed under UV light with a Gel Logic 212 Pro photo-imager $\left(\right.$ Carestream $\left.{ }^{\circledR}\right)$.

\section{Genetic divergence analysis}

Through analysis of the electrophoresis pattern, the bands were classified as discrete variables, a value of 1 being assigned for their presence and 0 for their absence, forming a binary matrix. With data from the matrix, the GENES software (Cruz, 2013) was employed to calculate genetic dissimilarity, using the complement of the Jaccard similarity index (1901), as shown in expression 1 below:

$$
D i j=\frac{\mathrm{a}}{\mathrm{a}+\mathrm{b}+\mathrm{c}}
$$

where: $a$ is the presence of bands in individuals $i$ and $j, b$ is the presence of bands in individual $i$ and absence in individual $j$, and $c$ is the absence of bands in individual $i$ and presence in individual $\mathrm{j}$.

From the dissimilarity matrix, a dendrogram was constructed using the Unweighted Pair Group Method with Arithmetic Mean (UPGMA) in the R v 3.4.0 software (R Core Team, 2017); the cophenetic correlation coefficient (r) was calculated to verify the fit of the graph to the matrix. To calculate the cut-off point, the methodology described by Mojena (1977) was used, as shown in expression 2 below:

$$
P c=m+k \cdot S d
$$

where: $m$ is the mean, $k$ is a constant (1.25) and $S d$ is the standard deviation. 
The modified Tocher method (sequential) (Vasconcelos et al., 2007) was also used to group the genotypes in order to confirm the number of groups formed and genotype separation.

The percentage of polymorphism corresponded to the ratio between the number of polymorphic bands generated by each primer and the total number of bands in the study; the Polimorphic Information Content (PIC) for each primer was calculated according to expression 3 (Anderson et al. 1993):

$$
P I C_{i}=1-\sum_{j} p_{i j}^{2}
$$

where: $\mathrm{p}_{\mathrm{ij}}$ is the frequency of allele $j$ in marker $i$.

\section{RESULTS AND DISCUSSION}

The molecular analysis showed amplification for 16 of the 25 ISSR markers tested. Of these, 14 were polymorphic and generated a total of 80 bands, which presented $76 \%$ polymorphism (Table 2).

When studying cowpea genotypes from Brazil and Nigeria using ISSR markers, Dias et al. (2015) found 76\% polymorphism, a high value and silimar to that found in our study; while Ghalmi et al. (2010), studying local varieties of the species from Africa, found $63 \%$, a value also considered high. The high values for polymorphism provided by ISSR primers reflect their coverage of the genome, since microsatellites, besides being abundant, are well distributed (Mahfouz, 2015).

The size of the DNA fragments ranged from 100 to $1600 \mathrm{bp}$, values similar to those found for this species by Dias et al. (2015), of 300 to $1400 \mathrm{bp}$, and for the genus Vigna by Ajibade et al. (2000), of 200 to $1500 \mathrm{bp}$.

The mean number of amplified bands per primer was 5.71. The primers with the highest number of bands were I- 825 and UBC-828, with 10 and 8 bands respectively. The number of polymorphic bands per primer ranged from 1 (I-808) to 9 (I-825) and for these primers, the contribution to polymorphism ranged from 1.25 to 10.59 respectively.

Table 2. Identification and sequence of the polymorphic ISSR primers used in the analysis, number of amplified bands $(\mathrm{AB})$, number of polymorphic bands $(\mathrm{PB})$ and percentage of polymorphism.

\begin{tabular}{|c|c|c|c|c|c|}
\hline & \multirow[b]{2}{*}{ Primer } & \multirow{2}{*}{ Sequence (5'-3') } & \multicolumn{2}{|c|}{ Number of bands } & \multirow{2}{*}{ Polymorphism (\%) } \\
\hline & & & $\mathbf{A B}$ & PB & \\
\hline 1 & I-807 & AGAGAGAGAGAGAGAGT & 7 & 6 & 7.50 \\
\hline 2 & I-808 & AGAGAGAGAGAGAGAGC & 4 & 1 & 1.25 \\
\hline 3 & $\mathrm{I}-810$ & GAGAGAGAGAGAGAGAT & 6 & 4 & 5.00 \\
\hline 4 & $\mathrm{I}-825$ & ACACACACACACACACAT & 10 & 9 & 11.25 \\
\hline 5 & $\mathrm{I}-841$ & GAGAGAGAGAGAGAGAYC & 4 & 4 & 5.00 \\
\hline 6 & I-842 & GAGAGAGAGAGAGAGAYG & 4 & 4 & 5.00 \\
\hline 7 & UBC-807 & AGAGAGAGAGAGAGAGT & 4 & 4 & 5.00 \\
\hline 8 & UBC-808 & AGAGAGAGAGAGAGAGC & 3 & 3 & 3.75 \\
\hline 9 & UBC-809 & AGAGAGAGAGAGAGAGG & 4 & 2 & 2.50 \\
\hline 10 & UBC-811 & GAGAGAGAGAGAGAGAYC & 6 & 3 & 3.75 \\
\hline 11 & UBC- 825 & ACACACACACACACACT & 8 & 5 & 6.25 \\
\hline 12 & UBC- 828 & TGTGTGTGTGTGTGTGA & 8 & 8 & 10.00 \\
\hline 13 & UBC-862 & AGCAGCAGCAGCAGCAGC & 6 & 4 & 5.00 \\
\hline 14 & UBC-873 & GACAGACAGACAGACA & 6 & 4 & 5.00 \\
\hline Total & & & 80 & 61 & 76.25 \\
\hline
\end{tabular}

$\mathbf{Y}=$ pyrimidine $(\mathrm{C}$ or $\mathrm{T})$. 
Five primers displayed polymorphism for each band generated (I-841, I-842, UBC807, UBC-808 and UBC-828); the remainder presented monomorphic bands. The I-808, UBC-809, UBC-808 and UBC-811 primers gave the smallest numbers of polymorphic bands, which were 1, 2, 3 and 3 respectively. However, the data provided by these primers also generated information, which can be confirmed by analyzing the PIC of each primer (Table 3) and of each band (Figure 1).

The PIC of each primer ranged from 0.13 (I-807) to 0.66 (UBC-808). When studying the crop using ISSR markers, Dias et al. (2015) found similar values, ranging from 0.234 to 0.666 .

Table 3. Frequency of the amplified bands and polymorphic information content (PIC) of the polymorphic ISSR primers used in the genetic analysis of Vigna unguiculata.

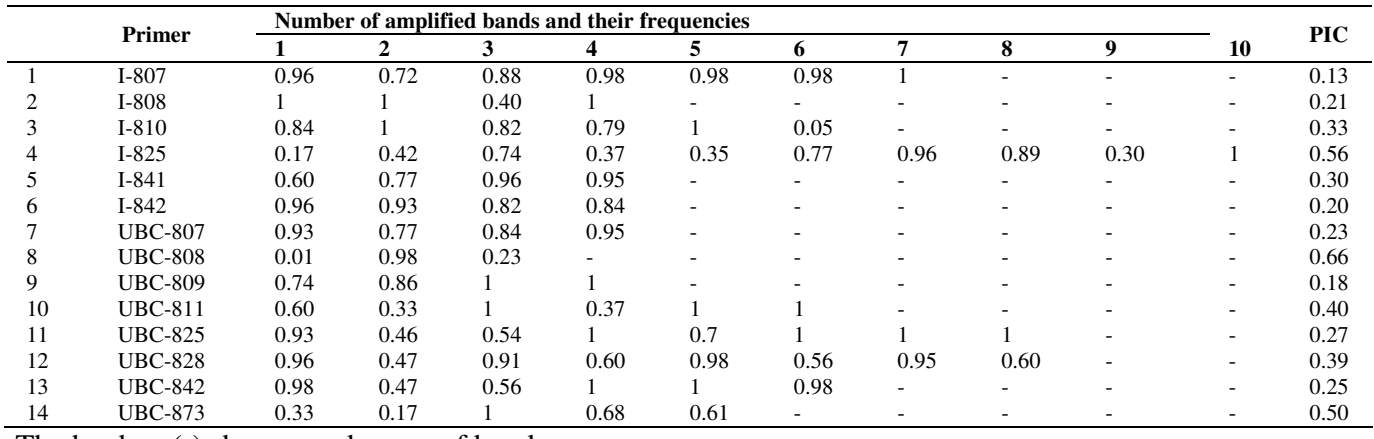

The hyphen (-) shows an absence of bands.

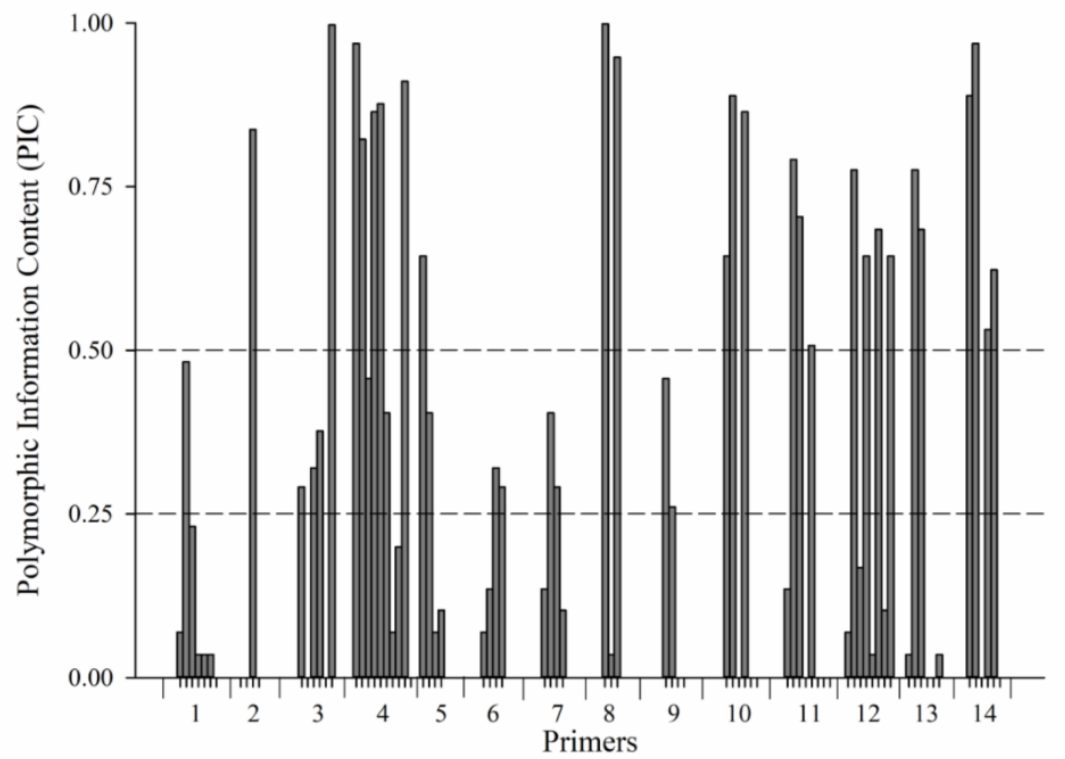

Figure 1. Polymorphic information content (PIC) of each band generated by the primers used in the study of cowpea landraces. 
Uninformative primers (PIC <0.25), reasonably informative primers $(0.5<\mathrm{PIC}$ $<0.25)$ and highly informative primers $(0.5<$ PIC) were found (Botstein et al., 1980). Only $35.7 \%$ of the primers presented a low PIC, revealing the large amount of information generated by the study. In addition, when evaluating the PIC of each generated band separately, even primers classified as uninformative gave bands with a high PIC (Figure 1), giving important data for the study of the genetic diversity of genotypes.

The frequency values of the bands have a direct relationship with the PIC of these markers, since for high-frequency markers, i.e. which appear in a great number of the genotypes, the values for PIC are reduced, while among those that appear in few genotypes the opposite occurred. The I-807 primer, which had the lowest value for PIC (0.13), displayed high frequencies of greater than 0.70 in all the amplified bands, while the UBC808 primer, with a PIC of 0.66 , displayed two bands of low frequency, less than 0.25 . Thus, when the marker appears with less frequency in the genotypes, its informative power is greater, since it has a larger capacity to differentiate individuals.

In Figure 1, it can be seen that $76.25 \%$ of the amplified markers generated useful polymorphic information in differentiating the genotypes under study, $48.75 \%$ presented PIC values greater than 0.25 , and $32.5 \%$ gave values greater than $0.5 \%$. This shows the efficiency of the primers that were selected. In herbaceous legumes, such as the cowpea, which tend to be more genetically uniform, it is advisable to use primers with AC and AG sequences, such as those adopted in this study (Dos Santos et al., 2013).

From the genetic distances, the individuals were grouped according to the UPGMA hierarchical method based on the Jaccard similarity index, forming six distinct groups (Figure 2). The mean genetic distance between the genotypes was 0.1743 ; the most-similar genotypes were 53 (Sempre verde) and 54 (Pitiúba), with a genetic distance of 0.0526 , while the most divergent were 42 (Roxão) and 49 (Cojó), with a genetic distance of 0.31 . Genotypes 53 and 54 were separated by only five bands, which demonstrate the usefulness of molecular studies for fingerprinting and registering genotypes.

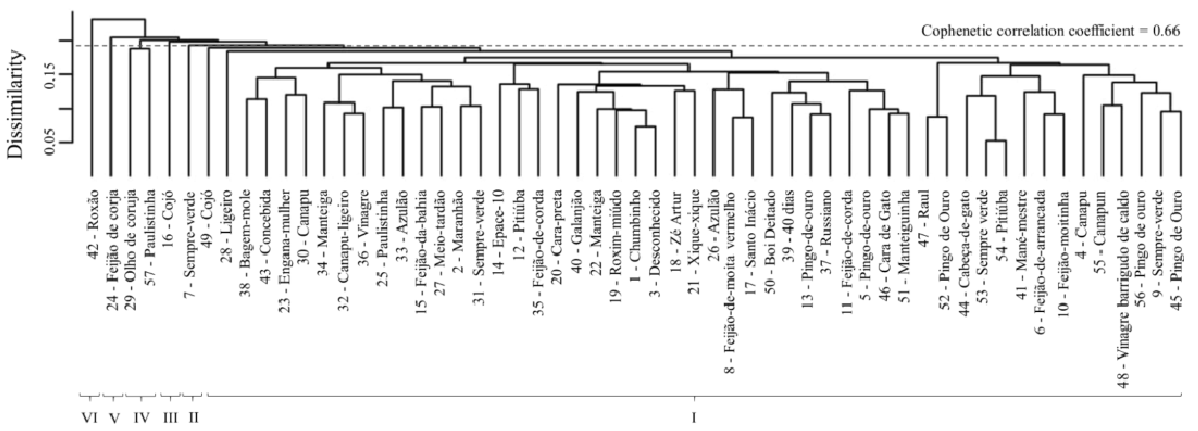

Figure 2. Dendrogram representing the genetic distances of the 57 genotypes under study, obtained by the unweighted pair group method (UPGMA), based on the Jaccard index.

Some genotypes having the same name are present in the same group (Figure 2): genotypes 26 and 33 (Azulão), genotypes 4, 30 and 55 (Canapu), genotypes 11 and 35 (Feijão-de-corda), genotypes 22 and 34 (Manteiga), genotypes 5, 13, 45, 48 and 52 (Pingo de ouro), genotypes 12 and 54 (Pitiúba), and genotypes 9, 31 and 53 (Sempre Verde). The name of a local variety of cowpea may designate different varieties, and different names 
may designate the same variety, so morphological and molecular characterization is necessary to clarify synonyms and aid in research on these varieties (Gbaguidim et al. 2013).

Genotypes of the same name include landraces and control cultivars, and there is great similarity between them; however, analysis using molecular markers made it possible to detect polymorphism, demonstrating that they display genetic variation. Such varieties may have had their origin in the cultivars, but due to management and selection by farmers over the years, together with natural selection and possible crosses, they may have undergone genetic alteration.

Such variation is often not found in morphological analyse, which would suggest repeated genotypes; but from analysis at the DNA level, it is possible to obtain precise information, and conclude that the genetic materials are different and should therefore be preserved in a germplasm collection. The polymorphism found by analysis with ISSR markers makes it possible to identify the genotypes, and even to reveal their genetic relationships, which is useful information for breeding programs (Mahfouz, 2015).

When assessing genetic diversity in local varieties of Algerian cowpea using ISSR markers, Ghalmi et al. (2010) found genetic distances ranging from approximately 0.025 to 0.325. Ali et al. (2015), when studying 252 genotypes of the species collected in the Sudan using codominant markers, which present a large amount of information, saw a variation in genetic distance of 0.031 to 0.303 . Both results are very close to those found in our study, and this shows a possible relationship between the genotypes, which may share a common origin. This is because the varieties grown in Brazil are believed to have been introduced from Africa, which according to Tan et al. (2012) is the probable origin of the species.

Panella and Gepts (1992), found low values for polymorphism and genetic distance in this species; this may have been due to a narrowing of its genetic base caused domestication, despite the large variation found in such morphological characteristics as seed color and pod type. Asare et al. (2010) confirm this assertion, and further state that this situation is maintained by the inherent self-pollination mechanism of the species.

Table 4 shows the grouping made by the sequential Tocher method, an optimization method that guarantees the maintenance of smaller distances within a group than between groups, and allows grouping genotypes with greater proximity (Vasconcelos et al., 2007). The division of genotypes into groups by the UPGMA method is also shown in this Table 4.

\begin{tabular}{|c|c|c|}
\hline \multirow{2}{*}{ Group } & \multicolumn{2}{|c|}{ Method } \\
\hline & Modified Tocher & UPGMA \\
\hline I & $\begin{array}{l}3,5,6,9,10,13,15,19,25,27,37,39,45,46,47,48,50,51, \\
53,55,56\end{array}$ & $\begin{array}{l}1,2,3,4,5,6,8,9,10,11,12,13,14,15,17,18,20,21, \\
22,19,23,25,26,27,28,30,31,32,33,34,35,36,37, \\
38,39,40,41,43,44,45,46,47,48,49,50,51,52,53, \\
54,55,56,57\end{array}$ \\
\hline II & $1,2,8,11,12,17,18,20,21,22,23,26,31,32,35,36,40$ & 7 \\
\hline III & $41,44,52,57$ & 16 \\
\hline IV & $4,7,14,16,28,29,30,33,34,38,43,49,54$ & 29,57 \\
\hline $\mathrm{V}$ & 24 & 24 \\
\hline VI & 42 & 42 \\
\hline
\end{tabular}


The Tocher optimization method and the Unweighted Pair Group Method (UPGMA) were selected as they form concordant and coherent groups, confirming the selection of possible parents (Cargnelutti Filho et al., 2008). Using these two clustering methods, seven distinct groups were formed, and a 38.59\% coincidence in genotype distribution was found.

Genotypes separated into different groups by the two methods can therefore be selected as parents in breeding programs. Combining clustering data at the largest genetic distances, the most suitable pairs for selecting parents are those formed by variety 42 (Roxão) with varieties 49 (Cojó), 16 (Cojó), 11 (Feijão-de-corda), 33 (Azulão) and 2 (Maranhão).

The use of divergent parents, in addition to maximizing the chances of superior segregants, enlarges the genetic base (Dos Santos et al., 2015). Cluster analysis is therefore of great importance in breeding programs, as an aid in identifying these genotypes (Cargnelutti Filho et al., 2008). In addition to molecular evaluation, agronomic evaluations are essential for choosing the best parents, and these data taken together contribute greatly to the success of breeding programs.

\section{CONCLUSIONS}

The ISSR markers that were selected for this study were efficient in identifying the genetic variability of the species, showing high values for polymorphism and polymorphic information content. Nevertheless, the values of genetic distances found between the varieties under study were low, suggesting a narrow genetic base in this species.

The clustering methods were efficient in separating individuals, forming the same number of groups, and association of these data with genetic distance; this allowed the selection of the most promising crosses, involving variety 42 (Roxão) with varieties 49 (Cojó ), 16 (Cojó), 11 (Feijão-de-corda), 33 (Azulão) and 2 (Maranhão).

Absence of genetically identical varieties among those under evaluation was verified through the use of ISSR markers, allowing informed decision-making regarding their introduction as accessions in germplasm banks.

\section{ACKNOWLEDGMENTS}

The authors would like to thank the Fundação Cearense de Apoio ao Desenvolvimento Científico e Tecnológico (FUNCAP) for funding.

\section{REFERENCES}

Ajibade SR, Weeden NF and Chite SM (2000). Inter simple sequence repeat analysis of genetic relationships in the genus Vigna. Euphytica 111: 47-55.

Ali ZB, Yao KN, Odeny DA, Kyalo M, et al. (2015). Assessing the genetic diversity of cowpea [Vigna unguiculata (L.) Walp.] accessions from Sudan using simple sequence repeat (SSR) markers. Afr. J. Plant Sci. 9: 293-304.

Almeida CMA, Lima SEN, Lima GSA, Brito JZ, et al. (2009). Caracterização Molecular De Cultivares De Cana-DeAçúcar. Ciência Agrotec. 33: 1771-1776.

Anderson JA, Churchill GA, Autrique JE, Tanksley SD, et al. (1993). Optimizing parental selection for genetic linkage maps. Genome 36: 181-186.

Asare AT, Gowda BS, Galyuon IKA and Aboagye LL (2010). Assessment of the genetic diversity in cowpea (Vigna unguiculata L. Walp.) germplasm from Ghana using simple sequence repeat markers. Plant Genet. Resour. 8: 1-9. 
Botstein D, White RL, Skolnick M and Davis RM (1980) Construction of a Genetic Linkage Map in Man Using Restriction Fragment Length Polymorphisms. Am. J. Hum. Genet. 32: 314-331.

Brush SB (1991). A farmer-based approach to conserving crop germplasm. Econ. Bot. 45: 153-165.

Cargnelutti Filho A, Ribeiro ND, Reis RCP, Souza JR, et al. (2008). Comparação de métodos de agrupamento para o estudo da divergência genética em cultivares de feijão. Ciênc. Rural 38: 2138-2145

Chen H, Chen H, Hu L, Wang L, et al. (2017). Genetic diversity and a population structure analysis of accessions in the Chinese cowpea [Vigna unguiculata (L.) Walp.] germplasm collection. Crop J. 5: 363-372.

Cruz CD (2013). GENES - a software package for analysis in experimental statistics and quantitative genetics. Acta Sci. 35: 271-276.

Dias FTC, Bertini CHCM, Silva APM and Cavalcanti JJV (2015). Genetic variability in early-cycle erect cowpea analysed with RAPD and ISSR markers. Rev. Ciênc. Agron. 46: 563-572.

Dos Santos A, Braga DC, Correa AM, Melo CLP, et al. (2015). Escolha de genitores de feijão-comum baseado na divergência genética Parents. Agrarian 8: 235-245.

Dos Santos RC, Queiroz CM, Batista VGL, Silva CRC, et al. (2013). Variabilidade de progênies F2 de amendoim geradas por meio de genitores. Rev. Ciênc. Agron. 44: 578-586.

Doyle JJT and Doyle JL (1990). Isolation of plant DNA from fresh tissue. Focus 12: 13-15, 1990.

Egbadzor KF, Ofori K, Yeboah M, Aboagye LM, et al. (2014). Diversity in 113 cowpea [Vigna unguiculata (L) Walp] accessions assessed with 458 SNP markers. Springer Plus 3: p. 541.

Embrapa (2016). Dados de conjuntura da produção de feijão comum (Phaseolus vulgaris L.) e caupi (Vigna unguiculata (L.) Walp) CEARÁ (1985 - $\quad$ 2016). Avaliable at [http://www.cnpaf.embrapa.br/socioeconomia/docs/feijao/dadosConjunturais_feijao_ceara.htm]. Accessed June 02, 2018.

Fonseca MA, Bianchini PC, Carvalho Neto MF, Santos RR, et al. (2015). Ferramentas participativas para diagnóstico da agrobiodiversidade e identificação de agricultores guardiões. Cad. Agroec. 10: 1-5.

Gajera HP, Domadiya RK, Patel SV and Golakiya BA (2014). Appraisal of RAPD and ISSR Markers for Genetic Diversity Analysis among Cowpea (Vigna unguiculata L.) Genotypes. J. Crop Sci. Biotechnol. 17: 79-88.

Gbaguidim AA, Dansi A, Loko LY, Dansi M, et al. (2013). Diversity and agronomic performances of the cowpea (Vigna unguiculata Walp.) landraces in Southern Benin. Int. Res. J. Agric. Sci. Soil Sci. 3: 121-133.

Ghalmi N, Malice M, Jacquemin J-M, Ounane S-M, et al. (2010). Morphological and molecular diversity within Algerian cowpea (Vigna unguiculata (L.) Walp.) landraces. Genet. Resour. Crop Evol. 57: 371-386.

Jaccard P (1901). Étude comparative de la distribution florale dans une portion des Alpes et des Jura. Bull. Soc. Vaudoise Sci. Nat. 37: 547-579.

Mahfouz HM (2015). Assessment of genetic diversity in cowpea (Vigna unguicalata) using SDS-PAGE, Random Amplified Polymorphic DNA (RAPD) and Inter-Simple Sequence Repeat (ISSR) markers. Egypt. J. Genet. Cytol. 44: 75-91.

Mojena R (1977). Hierarchical Grouping Methods and Stopping Rules : An Evaluation. Comput 20: 359-363.

Panella L and Gepts P (1992). Genetic relationships within Vigna unguiculata (L.) Walp. based on isozyme analyses. Genet. Resour. Crop Evol. 39: 71-88.

R CORE TEAM (2017). R: A language and environment for statistical computing. R Foundation for Statistical Computing. Vienna, Austria.

Stoilova T and Berova M (2014). Morphological and Agrobiological Study on Local Germplasm of Common Beans (Phaseolus vulgaris L.) and Cowpea (V. unguiculata L.). Biotechnol. Biotec. Equip. 23: 385-388.

Tan H, Tie M, Luo Q, Zhu Y, et al. (2012). A Review of Molecular Makers Applied in Cowpea (Vigna unguiculata L. Walp.) Breeding. J. Life Sci., 6: 1190-1199.

Tantasawat P, Trongchuen J, Prajongjai T, Seehalak W, et al. (2010). Variety identification and comparative analysis of genetic diversity in yardlong bean (Vigna unguiculata spp. sesquipedalis) using morphological characters, SSR and ISSR analysis. Sci. Hortic. 124: 204-216.

Thermo Scientific (2010). Nucleic Acid - Thermo Scientific NanoDrop Spectrophotometers. Avaliable at [https://tools.thermofisher.com/content/sfs/brochures/Thermo-Scientific-NanoDrop-Products-Nucleic-AcidTechnical-Guide-EN.pdf]. Accessed: 1 July 2017.

Thierfelder C, Rusinamhodzi L, Setimela P, Walker F, et al. (2016). Conservation agriculture and drought-tolerant germplasm: Reaping the benefits of climate-smart agriculture technologies in central Mozambique. Renew. Agr. Food Syst. 31: 414-428.

Vasconcelos ES, Cruz CD and Bhering LL (2007). Método alternativo para análise de agrupamento. Pesq. Agropec. Bras. 42: 1421-1428.

Wang H-Z, Feng S-G, Lu J-J, Shi N-N, et al. (2009). Phylogenetic study and molecular identification of 31 Dendrobium species using inter-simple sequence repeat (ISSR) markers. Sci. Hortic. 122: 440-447. 